\title{
MAKALAH MANAJEMEN PROYEKSI SI
}

\author{
SUPRI HARDIANSYAH \\ 175100021
}

Universitas Mitra Indonesia, Sistem Informasi

Suprihardiansyah.student@umitra.ac.id

\section{BAB I PENDAHULUAN}

\section{Abstrak}

Manajemen atau pengelolaan proyek (selanjutnya ditulis manajemen proyek saja) adalah suatu disiplin ilmu pada era tahun 1950 -an, Amerika bangsa yang pertama kali menggunakan ilmu manajemen proyek. Henry Gantt dapat dikatakan bapak dari ilmu manajemen proyek, dan namanya pun menjadi metode yang digunakan, bernama "Gantt Chart". Perlu diingat bahwa mempelajari Manajemen Proyek itu tidak terlalu sulit, karena didalamnya terdapat hal-hal yang terbiasa dilakukan oleh manusia, hanya ditambahkan sedikit logika dan aturan yang khusus. Sedangkan Proyek itu usaha yang harus dilakukan dari awal hingga akhir pada suatu kejadian,yang mempunyai batasan waktu - anggaran - sumber daya yang dibutuhi oleh pelanggan. Meskipada akhir tujuan dari adanya proyek adalah untuk memuaskan pelanggan.

Maksudnya begini, ketika ada suatu perusahaan besar maupun kecil memanajemen proyek, yang terpenting adalah waktu yang tepat dalam membuat dan memustuskan prediksi, serta penggunaan sumber daya dan laporan dalam penyampaian produk atas hasil dari proyek yang dijalankan.

Lalu bagaimana kita mengetahui bahwa itu adalah "proyek"?

Diperlukan beberapa ciriciri atau karakteristik dari proyek, yaitu: ada sasaran atau tujuan, memiliki rentang waktu atau deadline, waktu biaya dan syarat kerja yang lengkap, berurutan dari a hingga $\mathrm{z}$, terkadang merupakan sesuatu event atau kejadian yang sebelumnya belum pernah dilakukan.

1.1 Latar Belakang

Sebagai mahasiswa sistem informasi kita dituntut untuk memahami bagaimana manajemen proyek sistem informasi itu agar ilmu ini bisa di implementasikan dalam kehidupan nyata.Untuk mengetahui secara lebih jelas tentang manajemen proyek sistem informasi maka selanjutnya akan dibahas lebih mendetail mulai dari pengertian hingga metodologi umum pelaksanaan proyek sistem informasi. 2 
1.2. Rumusan Masalah

a. Pengertian manajemen, proyek dan manajemen proyek. b. Kebijakan dan Perencanaan Proyek

Sistem Informasi.

c. Metodologi Umum

Pelaksanaan Proyek

Sistem Informasi (

Metode

Generik).

1.3. Tujuan dan Manfaat

a. Untuk mengetahui dan memahami pengertianpengertian manajemen, proyek dan manajemen proyek.

b. Mengetahui kebijakan dan perencanaan proyek sistem informasi.

c. Mengetahui

Metodologi Umum

Pelaksanaan Proyek

Sistem

Informasi

(MetodeGenerik).

BAB II PEMBAHASAN

2.1. Pengertian

Manajemen, Proyek dan

Manajemen Proyek

2.1.1 Pengertian

Manajemen

Manajemen merupakan

sebuah proses terpadu

dimana individu- individu

sebagai bagian dari

organisasi yang dilibatkan

untuk merencanakan,

mengorganisasikan,

menjalankan dan

mengendalikan aktifitas-

aktifitas, yang

kesemuanya diarahkan

pada sasaran yang telah

ditetapkan dan

berlangsung terus

menerus seiring dengan

berjalannya waktu. Agar

proses manajemen

berjalan lancar, diperlukan sistem serta

struktur organisasi yang

solid. Pada organisasi

tersebut, seluruh

aktifitasnya haruslah

berorientasi pada

pencapaian

sasaran.Organisasi

tersebut berfungsi sebagai

wadah untuk menuangkan

konsep, ide-ide

manajemen. Jadi dapat

dikatakan bahwa

manajemen merupakan

suatu rangkaian tanggung

jawab yang berhubungan

erat satu sama lainnya.

Skill apa sih yang harus

di butuhkan bagi seorang

Manajer Proyek? Skill

yang dibutuhkan ada 4

titik, yaitu kepada Owner,

User, Lingkungan, dan

Team. Maksudnya, ketika

seorang manajer proyek

berurusan dengan owner

(komisaris perusahaan)

dapat memberikan

informasi berupa biaya

atau budget dari segi

finansial, serta resiko

kedepan yang akan

dihadapi. 3 
Ketika berbicara dengan user, dapat mengajak untuk menggunakan hasil dari proyek, baik melobi dan bujuk rayu. Lalu ketika berbicara dengan team tentunya harus memiliki keahlian tehnis, dapat mengarahkan, dan tentunya manajerial skill harus dimiliki. Terakhir ketika berbicara dengan lingkungan dalam hal ini pemerintah atau masyarakat sekitar, dapat meminta persetujuan atau izin akan adanya pengadaan proyek tersebut.

Manajer proyek adalah seseorang yang memiliki tanggung jawab terbesar atas pelaksanaan proyek. Pekerjaan utama dari manajer proyek adalah mengarahkan, mengawasi dan mengendalikan proyek dari awal sampai selesai. Hal-hal yang perlu dilakukan seorang manajer proyek adalah:

1. Manajer proyek harus mendefinisikan proyek, merinci proyek menjadi serangkaian tugas yang mudah dikelola, memperoleh sumber daya yang dibutuhkan, dan membentuk tim kerja untuk melaksanakan tugas- tugas tersebut. 2. Manajer proyek harus menetapkan tujuan akhir dari proyek dan memotivasi anggota timkerja untuk menyelesaikan proyek tepat waktu.
3. Manajer proyek harus menginformasikan kepada stakeholder tentang perkembangan pelaksanaan proyek secara periodik.

4. Manajer proyek harus mengenali resiko yang mungkin terjadi dan meminimalkan dampak terhadap penyelesaian proyek.

5. Manajer proyek harus beradaptasi terhadap perubahan-perubahan, karena tidak ada proyek yang $100 \%$ berjalan sesuai dengan yang direncanakan.

Berkaitan dengan tugastugas seorang manajer, maka area kemampuan yang perlu dimiliki oleh seorang manajer adalah: kepemimpinan, manajemen orang (konsumen, suplier, manajer dan kolega), komunikasi , negosiasi, perencanaan, manajemen kontrak, pemecahan masalah dan berpikir kreatif. Banyak kesalahan terjadi dalam mengelola sebuah proyek yang menyebabkan sering menjadi hambatan. 4 
Hambatan-hambatan yang mungkin terjadi adalah:

1. Komunikasi yang tidak baik (Poor

communication)

2. Persetujuan yang tidak jelas (Disagreement)

3. Kesalahpahaman

(Misunderstandings).

4. Suasana yang tidak mendukung (Bad

weather)

5. Pemogokan kerja

(Union strikes)

6. Konflik pribadi

(Personality conflicts)

7. Manajemen yang tidak baik (Poor management)

8. Definisi sasaran dan tujuan tidak jelas (Poorly defined goals and objectives)

Manajer proyek yang baik tidak menghindari semua resiko, tetapi menyiapkan proses dan prosedur standar untuk berusaha mencegah resiko yang mungkin terjadi seperti:

a. Keterlambatan penyelesaian proyek, pembengkakkan anggaran atau keingingan konsumen tidak terpenuhi.

b. Tidak konsisten antara proses dan prosedur yang digunakan manajer proyek.

c. Proyek tidak

bermanfaat dan

membuang-buang waktu

dan biaya.

d. Tidak sinerginya faktor internal dan eksternal yang mempengaruhi proyek.

2.1.2 Pengertian Proyek
Proyek merupakan suatu tugas yang perlu dirumuskan untuk mencapai sasaran yang dinyatakan secara kongkrit serta harus diselesaikan dalam suatu periode tertentu dengan menggunakan tenaga manusia dan alat-alat yang terbatas dan begitu kompleks sehingga dibutuhkan pengelolaan dan kerjasama yang berbeda dari yang biasanya digunakan. Menurut DI Cleland dan Wr. King (1987), proyek merupakan gabungan dari berbagai sumber daya yang dihimpun dalam organisasi sementara untuk mencapai suatu tujuan tertentu. Selain itu proyek juga: Bertujuan menghasilkan produk atau kerja akhir tertentu.

Dalam proses mewujudkan produk tersebut di atas, ditentukan jumlah biaya, jadwal, serta kriteria mutu. Bersifat sementara, dalam arti umurnya dibatasi oleh 5 
selesainya tugas. Titik

awal dan titik akhir

ditentukan dengan jelas.

Nonrutin, tidak berulang-

ulang. Macam dan

intensitas kegiatan

berubah sepanjang

berlangsungnya proyek.

Timbulnya suatu proyek antara lain dilatar

belakangi oleh:

a. Rencana pemerintah.

Misalnya proyek

pembangunan jalan.

b. Permintaan pasar.

Misalnya terjadi kenaikan permintaan suatu produk

dalam jumlah besar,maka perlu dibangun sarana

produksi baru.

c. Dari dalam perusahaan yang bersangkutan.

Misalnya suatu

perusahaan akan

memperbarui

(modernisasi) perangkat, sistem kerja, atau sistem

informasi yang lama agar lebih mampu bersaing.

d. Dari kegiatan

penelitian dan

pengembangan. Dari

kegiatan penelitian dan

pengembangan

diperkirakan dapat

dihasilkan produk baru

yang banyak manfaat dan

peminatnya, sehingga

dibangun fasilitas

produksinya.

Macam-Macam Proyek:

Menurut R.D Achibalt

(1976), macam-macam

proyek adalah sebagai

berikut:

a. Proyek Kapital

(Modal). Meliputi:

pembebasan tanah, pembelian material dan peralatan, desain mesin, dan kostruksi guna

pembangunan instalasi

pabrik baru.

b. Proyek pengembangan

produk baru adalah

kegiatan untuk

menciptakan produk baru

yang biasanya merupakan

gabungan antara proyek

kapital dan proyek riset

dan pengembangan.

Contoh : penemuan alat

elektronik karaoke.

c. Proyek penelitian dan

pengembangan berupa

kegiatan untuk melakukan

penelitian dengan sasaran

yang ditentukan.

d. Proyek sistem

informasi adalah kegiatan

yang sifatnya spesifik

dengan mempergunakan

alat-alat pemrosesan data

(data processing personal

dan alat-alat lainnya).

e. Proyek yang berkaitan

dengan manajemen:

perusahaan merancang

reorganisasi, perusahaan

merancang program

efisiensi, dan

penghematan merancang

diversifikasi. 6 
2.1.3 Manajemen Proyek Manajemen proyek merupakan suatu usaha merencanakan, mengorganisasi, mengarahkan, mengkoordinasi, dan mengawasi kegiatan dalam proyek sedemikian rupa sehingga sesuai dengan jadwal waktu dan anggaran yang telah ditetapkan. Suatu pekerjaan rutin biasanya berlangsung secara kontinu, berulangulang dan berorientasi ke proses. Sebagai suatu proses yangterus menerus, pekerjaan yang rutin tidak dianggap suatu proyek.

Manajemen proyek adalah suatu cara mengelola, mengarahkan, dan mengkoordinasikan sumber daya (manusia/material) disaat mulainya sebuah proyek hingga akhir untuk mencapai suatu tujuan, yang dibatasi oleh biaya, waktu, dan kualitas untuk mencapai kepuasan. Pengelola dalam sebuah proyek disebut sebagai Manajer Proyek. Manajer proyek bertanggung jawab untuk mengatur dan mengawasi semua kegiatan pelaksanaan proyek, agar sesuai dengan standar kualitas, biaya dan waktu. Dan tentunya selalu bertanggungjawab untuk selalu berkomunikasi dengan tim, atasan (owner), dan pelanggan (user). Maksudnya manajer harus mampu memberikan contoh tehnik, mampu mengambil keputusan yang tepat, dan pemimpin yang dapat memberikan informasi berupa laporan kepada atasan.

Manfaat manajemen proyek:

a) Mengidentifikasi fungsi tanggung jawab b) Meminimalkan tuntutan pelaporan rutin

c) Mengidentifikasi batas waktu untuk penjadwalan d) Mengidentifikasi metode analisa peramalan e) Mengukur prestasi terhadap rencana f) Mengidentifikasi masalah dini \& tindakan perbaikan $g$ ) Meningkatkan kemampuan estimasi untuk rencana

h) Mengetahui jika sasaran tidak dapat dicapai/terlampaui 7 
Contoh manajemen proyek diantaranya adalah: membangun sebuah stadion sepak bola, megelola penelitian berskala besar, melaksanakan pembedahan transplantasi organ tubuh, memasang lintas produksi, atau berjuang mendapatkan ijazah strata satu di suatu perguruan tinggi. Konsep Manajemen Proyek:

Manajemen proyek sistem informasi ditekankan pada tiga faktor, yaitu : manusia, masalah dan proses. Dalam pekerjaan sistem informasi factor manusia sangat berperan penting dalam suksesnya manajemen proyek. Pentingnya faktor manusia dinyatakan dalam model kematangan kemampuan manajement manusia (a people management capability maturity model atau PMCMM) yang berfungsi untuk meningkatkan kesiapan organisasi perangkat lunak (sistem informasi) dalam menyelesaikan masalah dengan melakukan kegiatan menerima, memilih, kinerja manajemen, pelatihan, kompensasi, pengembangan karier, organisasi dan rancangan kerja serta pengembangan tim.

Dasar-Dasar

Organisasional :

Organisasi adalah sistem yang saling mempengaruhi dan saling bekerja sama antara orang yang satu dengan orang yang lain dalam suatu kelompok untuk mencapai suatu tujuan tertentu yang telah disepakati bersama. Organisasi merupakan sistem maka terdiri dari beberapa elemen yaitu: a) orang, dalam organisasi harus ada sekelompok orang yang bekerja dan salah satunya ada yang memimpin organisasi tersebut.

b) tujuan, dalam organisasi harus ada tujuan yang harus dicapai, baik dalam jangka pendek maupun jangka panjang.

c) posisi, setiap orang yang ada dalam suatu organisasi akan menempati posisi atau kedudukannya masingmasing.

d) pekerjaan, setiap orang yang ada dalam organisasi tersebut mempunyai pekerjaan (job) masing-masing sesuai dengan posisinya. 8 
e) teknologi, untuk mencapai tujuan organisasi membutuhkan teknologi untuk membantu dalam pengolahan data menjadi suatu informasi.

f) struktur, struktur organisasi merupakan pola yang mengatur pelaksanaan pekerjaan dan hubungan kerja sama antar setiap orang yang ada dalam organisasi tersebut.

g) lingkungan luar, merupakan elemen yang sangat penting dan akan mempengaruhi keberhasilan suatu organisasi, misalnya adanya kebijakan pemerintah tentang organisasi.

Prinsip-prinsip organisasi adalah nilai-nilai yang digunakan sebagai landasan kerja bagi setiap orang yang ada dalam organisasi tersebut untuk mencapai keberhasilan tujuan yang telah disepakati. Prinsip-prinsip yang ada dalam organisasi meliputi :

a) Tujuan organisasi yang jelas

b) Tugas yang dilakukan harus jelas c) Pembagian tugas yang adil

d) Penempatan posisi yang tepat

e) Adanya koordinasi dan integrasi

2.2. Kebijakan dan

Perencanaan Proyek

Sistem Informasi

Sistem Informasi memiliki pengertian suatu sistem yang memiliki fungsi menghasilkan informasi-informasi yang dibutuhkan pihak user. Komponen yang termasuk sistem informasi meliputi infrastruktur hardware, Software dan ketersediaan sumber daya manusia bidang teknologi informasi. Proyek sistem informasi mencakup sebagian atau keseluruhan dari rangkaian aktivitas rekayasa pembangunan sistem informasi. Contoh-contoh proyek sistem informasi:

a) Proyek sistem informasi untuk mendukung pelaksanaan pemilu.

b) Proyek pembangunan infrastruktur EGovernment di Jawa Tengah.

c) Proyek pengembangan sistem CRM (Customer Relationship Management) pada di PTGaruda. 9 
d) Proyek pembansgunan sistem E-business pada PT. Global Jaya. e) Proyek penjualan elektronik (E-Commerce). Beberapa perbedaan karakteristik proyek sistem informasi dibandingkan dengan proyek bidang lain adalah sebagai berikut :

a) Memiliki tujuan untuk menghasilkan produk yang bersifat intangible (tidak dapat diperkirakan, tidak dapat dinyatakan secara jelas) seperti perangkat lunak, database, jaringan yang sulit untuk mengukur nilai manfaat dari produk tersebut.

b) Melibatkan teknologi yang sangat cepat usang, karena perkembangan yang sangat cepat.

c) Membutuhkan beragam sumber daya manusia dengan keahlian dan kompetensi yang beragam.

d) Ukuran yang dijadikan standar sulit dibakukan, karena sulit mengukur kualitas yang dimengerti berbagai pihak secara seragam.

Suatu sistem informasi dapat dikembangkan karena adanya kebijakan dan perencanaan terlebih dahulu. Tanpa adanya perencanaan sistem yang baik, pengembangan sistem tidak akan dapat berjalan sesuai dengan yang diharapkan. Tanpa adanya kebijakan pengembangan sistem oleh manajemen puncak, maka pengembangan sistem tidak akan mendapat dukungan darimanajemen puncak tersebut.

Kebijakan Sistem

Kebijakan untuk mengembangkan sistem informasi dilakukan oleh manajemen puncak karena manajemen menginginkan untuk meraih kesempatankesempatan yang ada yang tidak dapat diraih oleh sistem yang lama atau sistem lama mempunyai kelemahan (masalah) perencanaan sistem menyangkut estimasi (penafsiran, perkiraan, pendapat atau penilaian) sumber daya (kebutuhan-kebutuhan fisik dan tenaga kerja) dan biaya. Perencanaan sistem terdiri dari : perencanaan jangka pendek (periode 1-2 tahun) dan jangka panjang (periode sampai 5 tahun). 1111 
Perencanaan sistem biasanya ditangani oleh staf perencanaan sistem, departemenpengembanga $\mathrm{n}$ sistem atau depertemen pengolahan data.

Proses Perencanaan

Sistem Proses

perencanaan sistem dapat dikelompokkan dalam tiga proses utama, yaitu : 1. Merencanakan proyekproyek sistem

Tahapan proses perencanaan sistem yaitu

a) Mengkaji tujuan, perencanaan strategi dan taktik perusahaan.

b) Mengidentifikasi proyek-proyek sistem.

c) Menetapkan sasaran proyek-proyek sistem.

d) Menetapkan kendala proyek-proyek sistem (mis. Batasan biaya, waktu, umurekonomis, peraturan yang berlaku).

e) Menetukan prioritas proyek-proyek sistem. f)

Membuat laporan perencanaan sistem.

g) Meminta persetujuan manajemen.

2. Mempersiapkan proyek-proyek sistem yang akan dikembangkan Persiapan ini meliputi :

a) Menunjuk team analis dapat berasal dari departemen pengembangan yang ada atau dari luar perusahaan (konsultan).

b) Mengumumkan proyek pengembangan sistem.

3. Mendefinisikan proyek-proyek sistem yang dikembangkan
Melakukan studi untuk mencari alternative pemecahan terbaik yang paling layak untuk dikembangkan. Tahapan yang dilakukan yaitu :

a) Mengidentifikasi kembali ruang lingkup dan sasaran proyek system. b) Melakukan studi kelayakan.

c) Menilai kelayakan proyek system. d) Membuat usulan proyek system. e) Meminta persetujuan manajemen. Perkiraan Proyek Sistem Informasi Sekarang biaya merupakan elemen yang paling penting dan mahal dalam pengembangan sistem berbasis komputer. Perkiraan biaya yang salah atau kurang tepat dapat mengurangi keuntungan atau malah kerugian. Perkiraan biaya sistem informasi dan usaha tidak dapat dihitungdengan tepat, karena banyak variabel (manusia, teknikal, lingkungan) yang mempengaruhinya. 1212 
Untuk mencapai

perkiraan biaya dan usah yang dapat diandalkan, digunakan pilihan sebagai berikut :

$\square$ Memperkirakan waktu yang paling lama dari pengerjaan proyek.

$\square$ Perkiraan berdasarkan pada proyek yang sama.

$\square$ Menggunakan teknik dekomposis.

$\square$ Menggunakan satu atau lebih model empiris. Memperkirakan waktu untuk menyelesaikan setiap kegiatan merupakan bagian yang paling sulit, untuk itu butuh pengalaman dalam memperkirakan waktu yang diperlukan.

Penjadwalan tugas- tugas (kegiatan) dapat menggunakan :

1. Grafik Gantt Merupakan suatu grafik dimana ditampilkan kotak-kotak yang mewakili setiap tugas (kegiatan) dan panjang masing-masing setiap kotak menunjukkan panjang relatif tugastugas yang dikerjakan.

2. Diagram PERT (Program Evaluation and Review Techniques) Suatu program (proyek) diwakili dengan jaringan simpul dan tanda panah yang kemudian dievaluasi untuk menentukan kegiatan-kegiatan terpenting, meningkatkan jadwal yang diperlukan dan merevisi kemajuankemajuan saat proyek telah dijalankan.
Diagram PERT lebih baik dari Gantt, karena :

a. Mudah

mengidentifikasi tingkat

prioritas.

b. Mudah mengidentifikasi jalur kritis dan kegiatankegiatan kritis. c. Mudah menentukan waktu kendur. d. Penjadwalan proyek berbasis komputer. Menggunakan PC untuk membuat jadwal proyek lebih praktis dan menguntungkan. Contohprogram penjadwalan yaitu Ms Project, Symantec's Timeline dan Computer Associates' CA-Super Project. Proses pengembangan sistem informasi dikembangkan oleh pelaku-pelaku yang dapat dikatagorikan dalam 5 kelompok :

a) Manajer senior, yang bertugas mendefinisikan permasalahanpermasalahan bisnis dan sangat berpengaruh pada proyek tersebut. 1313 
b) Manajer proyek

(teknik), yang

merencanakan,

memotivasi,

mengorganisasi dan

mengontrol orang-orang

yang bekerja dalam

proyek tersebut (praktisi).

c) Praktisi, adalah orang

yang mempunyai

kemampuan teknis yang

dibutuhkan

untukmendapatkan

produk sistem informasi

(program aplikasi).

d) Pelanggan, adalah orang yang membutuhkan sistem informasi (PL) tersebut.

e) Pengguna akhir, orang yang berinteraksi dengan sistem informasi (PL) yang dikaitkan dengan penggunaan produk.

Sedangkan contoh

Manajemen Proyek antara lain:

1. Proyek pembuatan

Robot

2. Proyek Pembuatan

Website

3. Proyek Pembuatan

Software

4. Proyek Pembuatan

Aplikasi

2.3. Metodologi Umum

Pleaksanaan Proyek

Sistem Informasi

(Metodologi

Generik)

Pengembangan sebuah sistem informasi dalam sebuah perusahaan

dilakukan dengan

pendekatan manajemen

proyek (project

management). Lepas dari

berbagai variasi proyek-

proyek teknologi

informasi yang ada - seperti pembuatan

aplikasi, penerapan

perangkat lunak,

konstruksi infrastruktur

jaringan, dan lain

sebagainya - metodologi

yang dipergunakan secara

umum adalah sama.

Setidak-tidaknya ada

enam buah tahapan yang

harus dilalui :

perencanaan, analisa, desain, konstruksi, implementasi, dan pasca implementasi. Masingmasing konsultan atau para praktisi teknologi informasi biasanya memiliki variasinya masing-masing yang secara prinsip tidak lepas dari keenam langkah metodologi di atas. Secara umum, proyekproyek sistem informasi dalam perusahaan atau organisasi dapat dikategorikan dalam 3 kelompok besar.

a) Proyek yang bersifat pembangunan jaringan infrastruktur teknologi informasi, menyangkut hal-hal mulai dari pengadaan dan instalasi 1414 
computer sampai dengan

perencanaan

danpengembangan

infrastruktur jaringan

LAN (Local Area

Network) dan WAN

(Wide

AreaNetwork).

b) Implementasi dari paket program aplikasi yang dibeli di pasaran dan diterapkan diperusahaan, mulai dari software kecil seperti produk- produk retail Microsoft sampai dengan aplikasi terintegrasi berbasis ERP, seperti SAP dan BAAN.

c) Perencanaan dan pengembangan aplikasi yang dibuat sendiri secara khusus (customizedsoftware), baik oleh internal perusahaan maupun kerja sama dengan pihak luar seperti konsultan dan software house.

Lepas dari perbedaan tersebut, secara garis besar ada 6 tahap yang bisa dijadikan sebagai batu pijakan atau metodologi dalam melaksanakan aktivitas pengembangan tersebut. 2.3.1. Tahap Perencanaan Tahap perencanaan merupakan suatu rangkaian kegiatan semenjak ide pertama yang melatarbelakangi pelaksanaan proyek ini didapat, pendefinisian awal terhadap kebutuhan detail atau target yang harus dicapai dari proyek tersebut, penyusunan proposal, penentuan metodologi dan sistem manajemen proyek yang

digunakan, sampai dengan penunjukan tim dan instruksiuntuk mengeksekusi (memulai) proyek yang bersangkutan. Biasanya ada dua pihak yang terlibat langsung dalam proyek perencanaan ini yaitu :

a) Pihak yang membutuhkan (demand side) eksistensi dari suatu sistem informasi, dalam hal ini adalah perusahaan, lembaga, institusi atau organisasi yang bersangkutan.

b) Pihak yang berusaha menjawab kebutuhan tersebut (supply side) dalam bentuk pengembangan teknologi informasi. Kelompok ini biasanya merupakan gabungan dari parapersonel yang terkait dengan latar belakang ilmu dan pengetahuan yang beragam (multi disiplin), seperti ahli perangkat lunak, analisis bisnis dan manajemen, spesialis perangkat keras, programmer, sistem analis, praktisi hukum, manajer proyek dan beberapa karakteristik SDM lain yang terkait.15 15 
Dilihat dari segi

manajemen proyek sistem

informasi, output yang

harus dihasilkan tahap

perencanaan adalah

berupa jadwal detail dari

kelima tahapan

berikutnya menyangkut

masalah waktu, target

yang dapat disampaikan

(deliverable), personel

yang bertanggung jawab,

aspek- aspek keuangan

dan hal-hal lain yang

berkaitan dengan

pendayagunaan sumber

daya yang dipergunakan

dalam proyek. Sebagai

tambahan, standar-standar

dan prosedur yang akan

dipergunakan dalam

melakukan pengelolaan

proyek pun harus jelas

dan disepakati bersama

oleh seluruh anggota

personel.

2.3.2 Tahap Analisis

Secara prinsip ada 2

aspek yang jadi fokus

analisis, yaitu :

1. Aspek bisnis atau

manajemen

Analisis aspek bisnis

dimulai dengan

mempelajari karakteristik

perusahaan yang

bersangkutan, mulai dari

aspek-aspek historis,

struktur kepemilikan, visi,

misi, kunci keberhasilan

usaha (critical success

factors), ukuran kinerja

(performance

measurements), strategi,

program-program dan hal

terkait lainnya.

Tujuan dilakukannya

langkah ini :

a) Mengetahui posisi atau peranan teknologi informasi yang paling

sesuai dan relevan

diperusahaan (mengingat

setiap perusahaan

memiliki pandangan

tersendiri dan unik

terhadap sumber daya

teknologi yang dimiliki,

yang membedakannya

dengan perusahaan lain).

b) Mempelajari fungsi-

fungsi manajemen dan

aspek-aspek bisnis terkait

yang akan berpengaruh

(memiliki dampak

tertentu) terhadap proses

desain, konstruksi dan

implementasi.

2. Aspek teknologi

Analisis aspek teknologi

meliputi kegiatan-

kegiatan yang bersifat

menginventarisir aset

teknologi informasi yang

dimiliki perusahaan pada

saat proyek dimulai

dengan berbagai

tujuan,antara lain : 1616 
a) Mempelajari infrastruktur teknologi informasi yang dimiliki perusahaan dan tingkat efektivitas penggunaannya selama kurun waktu tersebut.

b) Menganalisis kemungkinan-

kemungkinan

diperlukannya

penambahan sistem di

kemudianhari (system

upgrading) sehubungan

akan

diimplementasikannya

teknologi baru.

Keluaran dari proses analisis di kedua aspek ini adalah isu-isu

(permasalahan) penting

yang harus segera

ditangani, dianalisis

penyebabnya, dampaknya

bagi bisnis perusahaan,

beberapa kemungkinan

scenario pemecahan

dengan segala resiko cost

atau benefit (laba atau

rugi) dan trade-off (tukar

tambah), serta pilihan

solusi yang

direkomendasikan.

Sebelum memasuki fase

desain, seluruh tim harus

paham tentang isu-isu ini

dan memiliki komitmen

untuk melanjutkan proyek

yang ada ke tahap

berikutnya sesuai dengan

skala prioritas yang telah

ditentukan (setelah

memilih scenario yang

disetujui bersama).

2.3.3. Tahap Desain

Pada tahap desain, tim

teknologi informasi

bekerja sama dengan tim

bisnis atau manajemen

melakukan perancangan komponen- komponen

sistem terkait. Tim

teknologi informasi

akanmelakukan

perancangan teknis dari

teknologi informasi yang

akan dibangun, seperti

sistem basis data, jaringan

computer, metode

interfacing, teknik

konversi data, metode

migrasi sitem

dansebagainya.

Model-model umum

seperti Flowchart, ER

Diagram, DFD dan lain

sebagainya dipergunakan

sebagai notasi umum

dalam perancangan sistem

secara teknis. Sementara

itu secara paralel dan

bersama-sama tim bisnis

atau manajemen akan

melakukan perancangan

terhadap komponen-

komponen organisasi

yang terkait seperti

prosedur $(\mathrm{SOP}=\mathrm{Standar}$

OperationProcedures),

struktur organisasi,

kebijakan-kebijakan,

teknik pelatihan,

pendekatan SDM dan

sebagainya. Tim ini pun

biasanya akan

mempergunakan model-

model umum seperti

Porter's Value Chain, 17

17 
Bussiness Process

Mapping, Strategic

Distinction Model, BCG

Matrix, dan lain-lain.

Jelas bahwa hasil tahap

ini, yang berupa cetak

biru rancangan sistem, secara teknis dan secara manajemen akan

dijadikan pegangan dalam proses konstruksi dan implementasi komponenkomponen pada sistem informasi yang akan dikembangkan.

2.3.4.Tahap Konstruksi

Berdasarkan desain yang telah dibuat, konstruksi atau pengembangan sistem yang sesungguhnya (secara fisik) dibangun. Tim teknis merupakan tulang punggung pelaksana tahap ini, mengingat semua hal yang bersifat konseptual harus diwujudkan dalam suatu konstruksi teknologi informasi dalam skala detail. Dari semua tahapan yang ada, tahap konstruksi inilah yang biasanya paling banyak melibatkan sumber daya terbesar, terutama dalam hal SDM, biaya, waktu. Control terhadap manajemen proyek pada tahap konstruksi harus diperketat agar tidak terjadi ketidak efisienan maupun ketida kefektifan dalam penggunaan beragam sumber daya yang ada (yang secara tidaklangsung akan berdampak langsung terhadap keberhasilan proyek sistem informasi yang diselesaikan secara tepat waktu).

Akhir dari tahap konstruksi biasanya berupa uji coba sistem. Perbaikan- perbaikan bersifat minor biasanya harus dilakukan setelah adanya masukan-masukan yang timbul setelah diadakannya evaluasi. 2.3.5. Tahap Implementasi Tahap Implementasi merupakan tahap yang paling kritis karena untuk pertama kalinya sistem informasi akan dipergunakan di dalam perusahaan. Biasanya, pendekatan yang dipergunakan oleh perusahaan adalah pendekatan cut off dan paralel.

a) Pendekatan cut off atau big-bang adalah suatu strategi implementasi yang memilih sebuah hari sebagai patokan dan terhitung mulai hari tersebut, sistem baru mulai dipergunakan dan sistem lama ditinggalkan sama sekali. 1818 
b) Pendekatan paralel

dilakukan dengan cara

melakukan pengenalan

sistem baru sementara

sistem lama belum

ditinggalkan, sehingga

dua buah sistem berjalan

secara paralel (kedua

sistem tersebut biasa

disebut testing

environment dan

production environment).

Pemilihan terhadap kedua

strategi tersebut

tergantung pada

perusahaan masing-

masing, karena masing-

masing strategi

implementasi memiliki

keuntungan dan kerugian

yang berbeda. Lepas dari

strategi yang dipilih,

pemberian pelatihan

(training) harus diberikan

kepada semua pihak yang

terlibat sebelum tahap

implementasi dimulai.

Selain untuk mengurangi

resiko kegagalan,

pemberian pelatihan juga

berguna untuk

menanamkan rasa

memiliki terhadap sistem

baru yang diterapkan,

sehingga seluruh jajaran

pengguna atau SDM

dengan mudah menerima

sistem tersebut dan

memeliharanya dengan

baik di masa- masa

mendatang. Evaluasi

secara berkala perlu

dilakukan untuk menilai

kinerja sistem baru yang

diterapkan dan untuk

mengetahui isu- isu

permasalahan yang

timbul. Tentu saja

pemecahan masalah

dalam tahap implementasi harus segera dicari agar

penggunaan sistem

tersebut efektif.

Proyek sistem informasi

biasanya ditutup setelah

tahap implementasi

dilakukan. Namun ada

satu tahapan lagi yang

harus dijaga

manajemennya, yaitu

tahap pasca implementasi.

2.3.6. Tahap Pasca-

implementasi

Dari segi teknis, yang

dimaksud dengan

aktivitas-aktivitas pasca

implementasi adalah

bagaimana manajemen

pemeliharaan sistem akan

dikelola (maintenance,

supports and services

management). Seperti

halnya sumber daya yang

lain, sistem informasi

akan mengalami

perkembangan

dikemudian hari.

Hal-hal seperti modifikasi

sistem, interfacing ke

sistem

lain,perubahan hak akses

sistem, penanganan

terhadap fasilitas pada

sistem yang rusak,

merupakanbeberapa

contoh dari kasus-kasus

yang biasa timbul dalam

pemeliharaan sistem. Di

sinilah perlunya

dokumentasi 1919 
yang baik dan transfer of knowledge dari pihak pembuat sistem ke SDM perusahaan untuk menjamin terkelolanya proses-proses

pemeliharaan sistem.

Tidak jarang terjadiperistiwa dimana perusahaan atau personel pembuat sistem sudah tidakdiketahui lagi lokasinyasetelah bertahun- tahun (mungkin perusahaannya tutup, atau yang menangani sistem sudah pindahke tempat kerja lain). Bisa dibayangkan bagaimana perusahaan pemakai sistem terpaksa membuang sistemnya (membuat sistem baru lagi) atau melakukan tambal sulam (yang secarateknis sangat berbahaya karena tingkat integritas data yang buruk) akibat tidak adanya dokumentasi teknis yang baik atau infrastruktur manajemen pemeliharaan yang efektif.

Dari segi manajemen, tahap pasca implementasi adalah berupa suatu aktivitas, harus ada personel atau divisi dalam perusahaan yang dapat melakukan perubahan atau modifikasi terhadap sistem informasi sejalan dengan perubahan kebutuhan bisnis yang teramat dinamis. Dengan kata lain, dalam era kompetisi sekarang, perusahaan harus mampu berubah dengan sangat cepat. Sistem informasi atau teknologi informasi bisa memerlukan waktu yang secara teknis tidak dapat beradaptasi terhadap perubahan kebutuhan bisnis perusahaan sudah selayaknya tidak mendapatkan tempat yang baik. Apakah teknologi informasi di perusahaanperusahaan dapat dengan mudah mengikuti perubahan kebutuhan bisnis secara cepat? Jika belum, sudah waktunya bagi pemimpin perusahaan untuk berbicara dengan departemen atau divisi yang bertanggung jawab terhadap teknologi informasi perusahaan Anda. Dan kenyataannya, sudah ada teknologi yang dapat menjawab kebutuhan ini, dan itu sudah terbukti efektif. Tidak ada tempat bagi perusahaan modern pada tahun 2000 yang masih menggunakan pendekatan sistem informasi dan teknologi informasi secara konservatif (bagi sebagian perusahaan besar di Indonesia pendekatan tersebut masih dianggap sebagai pendekatan termodern). Studi kasus Proyek Pembuatan Software Proses pembuatan software tidak cukup hanya dikerjakan dalam waktu beberapa hari saja. Ada beberapa tahapan yang harus dilalui dalam proses pembuatan software. Setiap tahapan

\section{1}


cukup lama, bisa satu

bulan, dua bulan, atau

bahkan satu tahun.

Tahapan- tahapan itu

yaitu : requirement

(perencanaan dan

analisa), design

(pembuatan), dan testing

(pengujian dan

pemeliharaan). Setiap

tahapan yang dilalui

terdapat beberapa

permasalahan-

permasalahan yang

timbul.

Pada permasalahan ini

akan dibahas beberapa

permasalahan yang timbul

dengan studikasus

pembuatan software

Sistem Informasi

Akademik dan juga akan

dibahas solusi yang dapat

diambil untuk mengatasi

beberapa permasalahan

tersebut. Pembahasan

permasalahan ini dibagi

dalam setiap tahapan

pembuatan software.

a) Tahap Requirement

Pada tahap ini, kegiatan

yamg paling banyak

dilakukan adalah dengan

melakukan interaksi

dengan user.

Permasalahan dalam

proses pembuatan

software yang dapat

timbul pada tahap

iniadalah :

1. Permasalahan

spesifikasi kebutuhan

Kebutuhan akan fitur dan report yang diinginkan

seringkali tidak sesuai dengan sistem yang ada.

Misalnya pada sistem

Informasi Akademik, user menginginkan report

pembayaranSPP, sedangkan sistem ini

hanya mengenai masalah

akademik perkuliahan.

2. Ketidak sepahaman

sistem antara developer

dan user Seringkali antara

developer dan user

dikarenakan perbedaan

pemahaman, terjadi

ketidak sepahaman

mengenai alur Sistem

Informasi Akademik,

misalnya alur mulai dari

mahasiswa bayar SPP,

daftar ulang, pengisian

FRS, proses perkuliahan

sampai nilai akhir UAS

keluar.

3. Metode analisa sistem

Metode analisa sistem

yang digunakan oleh

developer tidak sesuai

dengan kondisi/

behaviouruser.

b) Tahap Design

Pada tahap ini, merupakan tahap yang

dilakukan oleh developer.

Permasalahan dalam

proses pembuatan

software yang dapat

timbul pada tahap ini

adalah :

1. Metode pembuatan

software

Metode dan tools yang

digunakan hasilnya tidak

optimal, sesuai dengan

keinginan user.

2. Organisasi pembuatan

software 2222 
Tidak adanya koordinasi

pada saat proses

pembuatan software, sehingga terjadi modulmodul yang tidak dapat digabungkan. Misalnya tidak sesuainya nama tabel, field, atau tipe data yang digunakan.

c) Tahap Testing

Pada tahap ini, merupakan tahap pengujian software yang dilakukan antara developer dan user, dan diakhiri dengan pemeliharaan software. Permasalahan dalam proses pembuatan software yang dapat timbul pada tahap ini adalah :

1. Perubahan regulasi sistem

Adanya perubahan regulasi sistem, misalnya perubahan evaluasi penilaian dari 5 tingkat penilaian $(\mathrm{A}, \mathrm{B}, \mathrm{C}, \mathrm{D}, \mathrm{E})$ menjadi 7 tingkat penilaian $(\mathrm{A}, \mathrm{AB}, \mathrm{B}, \mathrm{BC}$, C, D, E). Hal ini menyebabkan perubahan tabel dan field nya.

2. Ketidak sesuaian keinginan user dengan software yang telah dibuat Pengujian software yang dilakukan antara user dan developer tidak memenuhi keinginan user.

3. Tidak adanya Risk Management Hal ini menyebabkan tidak ada langkah-langkah yang akan dilakukan apabila terjadi revisi atau pun pada masa garansi/ maintenance. Untuk mengatasi beberapa permasalahan tersebut diatas, perlu dilakukan analisa untuk mendapat solusinya. Ada beberapa solusi yang dapat diambil, antara lain :

1. Membuat dokumen kontrak antara developer dan user sebelum proses pembuatan software.

2. Perlu adanya assessment pada saat survey data, wawancara, ataupun analisa data. Assessment ini ditandangani kedua belah pihak, user dan developer.

3. Menggunakan requirement tool untuk proses requirement sehingga dapat dihasilkan requirement yang sesuai dengan kebutuhan user. 2323 
4. Menentukan Proces

Model yang akan

digunakan pada awal

proses pembuatan

software, dapat

menggunakan waterfall

model, RAD model,

spiral model, atau model

lainnya.

5. Membuat project management pada proses

pembuatan software

dengan dikoordinasi

seorang penanggung

jawab.

6. Menentukan software programming untuk semua modul yang akan dibuat, termasuk tabel, relasi, dan struktur data.

7. Membuat dokumen

Berita Acara Pengujian

Software sehingga dapat dinilai tingkat kepuasaan user terhadap software yang telah dibuat.

8. Developer melakukan evaluasi total setiap selesai pembuatan software sebelum pengujian.

Solusi yang lain secara teknis adalah membuat software Sistem Informasi Akademik yang dinamis, dimana user dapat melakukan update sistem secara mandiri dan berkala tanpa perlu berhubungan dengan developer kembali. Misalnya, membuat perubahan evaluasi penilaian, evaluasi absensi, aturan penilaian, perubahan kurikulum, dan sebagainya. Tetapi untuk membuat software Sistem Informasi Akademis yang dinamis tersebut memerlukan waktu yang tidak sedikit dan juga membutuhkan biaya yang cukup besar.

Maka hal yang paling penting dilakukan dalam proses pembuatan software Sistem Informasi Akademik adalah komunikasi yang intensif dan efektif antara user dan developer, baik itu pada tahap requirement, design, maupun testing. Dengan adanya komunikasi yang intensif danefektif tersebut maka dapat diketahui sampai seberapa jauh software dinamis yang dibutuhkanoleh user. Sehingga tingkat kepuasan user dapat terjaga. 2424 
BAB III

PENUTUP

3.1 Kesimpulan

1. Manajemen merupakan sebuah proses terpadu dimana individu-individu sebagai bagian dari organisasi yang dilibatkan untuk merencanakan, mengorganisasikan, menjalankan dan mengendalikan aktifitasaktifitas, yang kesemuanya diarahkan pada sasaran yang telah ditetapkan dan berlangsung terus menerus seiring dengan berjalannya waktu. 2. Menurut DI Cleland dan Wr. King (1987), proyek merupakan gabungan dari berbagaisumber daya yang dihimpun dalam organisasi sementara untuk mencapai suatu tujuantertentu.

3. Manajemen proyek adalah suatu cara mengelola, mengarahkan, dan mengkoordinasikan sumber daya (manusia atau material) disaat mulainya sebuah proyek hingga akhir untuk mencapai suatu tujuan, yang dibatasi oleh biaya, waktu, dan kualitas untuk mencapai kepuasan. 4. Lepas dari berbagai variasi proyek-proyek teknologi informasi yang ada seperti pembuatan aplikasi, penerapan perangkat lunak, konstruksi infrastruktur jaringan, dan lain sebagainya-metodologi yang dipergunakan secara umum adalah sama. Setidak-tidaknya ada enam buah tahapan yang harus dilalui: perencanaan, analisa, desain, konstruksi, implementasi, dan pasca implementasi.

3.2 Saran

Suatu sistem informasi dapat dikembangkan karena adanya kebijakan dan perencanaan terlebih dahulu. Tanpa adanya perencanaan sistem yang baik, pengembangan sistem tidak akan dapat berjalan sesuai dengan yang diharapkan.

\section{REFERENSI}

[1] A. S. Putra And O. M. Febriani,

"Knowledge Management

Online Application In Pdam

Lampung Province," In

Prosiding International

Conference On Information

Technology And Business

(Icitb), 2018, Pp. 181-187.

[2] A. S. Putra, O. M. Febriani, And

B. Bachry, "Implementasi

Genetic Fuzzy System Untuk

Mengidentifikasi Hasil Curian

Kendaraan Bermotor Di Polda

Lampung," J. Sist. Inf. Dan

Manaj. Basis Data, Vol. 1, No.

1, Pp. 21-30, 2018.

[3] O. M. Febriani And A. S. Putra,

"Sistem Informasi Monitoring

Inventori Barang Pada Balai

Riset Standardisasi Industri

Bandar Lampung," J. Inform.,

Vol. 13, No. 1, Pp. 90-98, 2014.

[4] Putra, Arie Setya. "2018 Artikel

Struktur Data, Audit Dan

Jaringan Komputer." (2018). 
[5] Putra, A. S. (2018, July 17).

Paperplain Fundamental Create

Application With Borland

Delphi 7.0 University Of Mitra

Indonesia. Retrieved From

Osf.Io/Pbrn9. 